Merokok di kalangan Remaja

\title{
Pengaruh Merokok Bagi Remaja Terhadap Perilaku dan Pergaulan Sehari-hari
}

Aprina Titin Setyani, Muhammad Ali Sodik

STIKes Surya Mitra Husada

aprinatitin22@gmail.com, alisodik2012@gmail.com

\begin{abstract}
Abstrak
Masa remaja merupakan masa dimana seorang individu mengalami peralihan dari satu tahap ke tahap berikutnya dan mengalami perubahan baik emosi,tubuh,mint pola perilaku, dan juga penuh dengan masalah-masalahRemaja cenderung memiliki rasa ingin tahu untuk merokok yang besar. Kebiasaan merokok bagi para remaja bermula karena kurangnya informasi dan kesalahpahaman informasi, termakan iklan atau terbujuk rayuan teman. Banyak yang beranggapan bahwa merokok dapat menghilangkan stress. Namun hal ini sangat tidak dibenarkan. Hal tersebut merupakan hanya efek dari nikotin yang sifatnya memberikan rasa tenang sesaat. Jika sudah merokok laungkan waktu untuk berhenti secepatnya dari kebiasaan buruk itu. Mulai dari hidup sehat dan teratur mengigat bahaya merokok bagi kesehatan yang sangat mengerikan. Carilah suasana pergaulan yang baru yang menjauhi dari kegiatan merokok.
\end{abstract}

Kata Kunci : Merokok, Remaja, Nikotin.

\section{Latar Belakang}

Masa remaja merupakan masa dimana seorang individu mengalami peralihan dari satu tahap ke tahap berikutnya dan mengalami perubahan baik emosi,tubuh,mint pola perilaku, dan juga penuh dengan masalahmasalah. Oleh karenanya, remaja sangat rentan sekali mengalami psikososial, yakni masalah psikis atau kejiwaan yang timbul akibat terjadinya perubahan sosial.
Sebenarnya seorang pelajar belum boleh merokok di kalangan sekolah, masyarakat atau kalangan yang lainya. Karena hal ini dapat berdampak buruk bagi kesehatannya. Biasanya ini dilakukan oleh para remaja karena kondisi emosi mereka yang tidak stabil membuat mereka melakukan segala hal. Hal ini di sebababkan kurangnya penyuluhan tentang bahay merokok di kalangan sekolahatau masyarakat. 
Merokok merupakan salah satu masalah yang sulit di pecahkan. Apalagi sudah menjadi masalah nasional, dan bahkan internasional. Hal ininmenjadi sulit, karena berkaitan dengan banyak fakto yang saling memicu, sehingga seolah-olah sudah menjadi lingkaran setan. Di tinjau dari segi kesehatan, merokok harus di hentikan karena menyebabkan kanker di penyumbatan pembuluh darah yang mengakibatkan kematia, oleh karena itu merokok harus di hentikan sebagai usaha pencegahan sedini mungkin. Terlebih diketahui bahwa sebagian besar adalah remaja sehingga perluadanya pencegahan dini yang dimulai dari pihak sekolah dan orang tua.

Para perokok merasakan nikmatnya merokok begitu nyata, sampai dirasa memberikan rasa menyenangkan dan menyegarkan sehingga setiap harinya harus menyisihkan uang untuk merokok. Kelompok lain, khususnya remaja pria, mereka menganggap merokok adalah merupakan ciri kejantanan yang membanggakan, sehingga mereka yang tidak merokok malah justru diejek. Padahal mereka sadar bahwa merokok dapat membahayakan kesehatan bahkan menimbulkan banyak penyakit serius. Banyak terdapat kandungankandungan yang berbahaya di dalam rokok sehingga menimbulkan dampak buruk bagi kesehatan.

\section{Kasus/Masalah}

Jakarta- Foto dua siswa SMK yang sedang merokok saat guru tengah mengejar di kelas menjadi viral di media sosial. Guru yang mengajar di kelas tersebut tidak mengetahui ada siswanya yang merokok saat jam pelajaranya. Begini kronologi kejadian seperti yang disampaikan Kepala SMK 38 PGRI Sedya Basuki kepada wartawan, kamis (27/7/2017) dalam pernyataan tertulis.

Pada hari rabu 26 Juli 2017, sekitar jam 12.30, kami ( Kepala Sekolah SMK PGRI 38) diberitahu oleh salah satu guru SMA PGRI ada postingan siswa yang sedang merokok di kelas. Siswa tersebut merokok di kelas dan ada guru yang sedang mengajar.

\section{Tinjauan pustaka}

Pengertian rokok menurut PP No. 81/1999 pasal 1 ayat 1 adalah hasil olahan tembakau terbungkus termasuk cerutu 
atau bentuk lainya yang

dihasilkan dari tanaman

Nicotiana tabacum, Nicotiana

rustica dan spesies lainya atau

sintetisnya yang mengandung

nikotin dan tara dengan atau

tanpa bahan tambahan.

Menurut Ogawa (dalam

Triyanti, 2006) dahulu perilaku

merokok di sebut sebagai suatu

kebiasaan atau ketagihan, tetapi

dewasa ini merokok di sebut

sebagai tobaco dependencyd

sendiri dapat didefinisikan

sebagai perilaku penggunaan

tembakau yang menetap,

biasanya lebih dari setengah

bungkus perhari.

1. Faktor-faktor yang mempengaruhi perilaku merokok

Menurut Juniarti(1991)

dalam Mu'tadin (2002)

dalam Poltekkes Depkes

Jakarta 1 (2012), faktor

yang mempengaruhi

kebiasaan merokok adalah

sebagai berikut :

a. Pengaruh Orang Tua

Salah satu temuan

remaja perokok

adalah bahwa anak-

anak muda yang

berasal dari rumah tangga yang tidak

bahagia, dimana

orang tua tidak

begitu

memperhatikan

anak-anaknya dan

memberikan

hukuman yang

keras.

b. Pengaruh teman

Semakin banyak

remaja yang

merokok maka

semakin besar

kemungkinan

teman-temanya

adalah perokok dan

demekian

sebaliknya. Dari

fakta tersebut ada

dua kemungkinan

yang terjadi.

Pertama, remaja tadi

terpengaruh oleh

teman-temanya, atau

bahkan temen-temen

remaja tersebut

dipengaruhi oleh

remaja tersebut.

c. Faktor kepribaian

Orang coba untuk

merokok karena

alasan ingin tahu tau

ingin melepaskan

diri dari rasa sakit 
fisik atau jiwa dan

membebaskan diri

dari kebosanan.

d. Pengaruh iklan

Melihat iklan

dimedia massa dan

elektronik ysng

menampilkan

gambaran bahwa

perokok adalah

lambang kejantanan

atau glamour.

Membuat remaja

sering kali terpicu

untuk meniru

perilaku perilaku

seperti yang ada di

dalam iklan tersebut

2. Aspek-Aspek Perilaku

Merokok

Aspek-aspek perilaku merokok menurut

Aritonang (dalam

Nasution,2007), yaitu:

a. Fungsi merokok dalam kehidupan sehari-hari

$\begin{array}{lr}\begin{array}{l}\text { Fungsi } \\ \text { ditunjukkan }\end{array} & \text { dengan } \\ \text { perasaan yang dialami si } & \\ \text { perokok, } & \text { seperti } \\ \text { perasaan yang } & \text { positif } \\ \text { maupun } & \text { perasaan } \\ \text { negatif. }\end{array}$

b. Intesitas merokok
Smet

mengklarifikasikan

perokok berdasarkan banyaknya rokok yang dihisap, yaitu:

a. Perokok berat yang menghisap lebih dari 15 batang rokok dalam sehari

b. Perokok sedang yang menghisap 514 batag rokok dalm sehari

c. Perokok ringan yang menghisap 1-4 batang rokok dalam sehari.

c. Tempat merokok Tipe perokok berdaarkan tempat ada dua (Mu’tadin,2002 dalam poltekes Depkes Jakarta I,2012) yaitu:

a. Merokok ditempat umum/publik

b. Merokok ditempattempat yang bersifat pribadi

d. Waktu Merokok

Perilaku merokok di pengaruhi oleh keadaan yang dialaminya pada saat itu, misalnya sedang berkumpul dengan teman. 
Ada tiga indikator yang biasanya muncul pada perokok:
a. Aktivitas fisik
b. Aktifitas psikologis
c. Intesitas merokok cukup tinggi.

\section{Pembahasan}

A. Pengertian rokok

Rokok adalah silinder dari kertas berukuran panjang antara 70-120 mm dengan diameter 10 $\mathrm{mm}$ yang berisi daun-daun tembakau yang telah di cacah. Rokok di bakar disalah satu ujungnya dan dibiarkan membara agar asapnya di hirup melalui mulut ujung lain. Bahan dasar rokok adalah tembakau. Tembakau terdiri dari berbagai bahan kimia yang dapat membuat seseorang ketagihan, walaupun mereka tidak ingin mencobanya lagi.

B. Dampak Perilaku Merokok

- Bagi diri sendiri

1. Merokok lebih banyak mendatangkan kerugian dibandingkan keuntungan bagi tubuh.

2. Menimbulkan sugesti kepada diri kita, bahwa jika kita tidak merokok mulut tidak enak dan asam.
3. Rasa ingin tahu, semangat untuk belajar, dan berbagai hal positif yang ada pada diri kita hilang ketika kita menjadi seorang perokok.

- Bagi orang lain

1. Ketika kita sedang merokok, asap rokok kita adapat mengganggu orang lain dan juga menyebabkan polusi udara.

2. Menyebabkan seseorang yang dekat dengan kita menjadi perokok pasif.

3. Jika membuang puntung rokok sembarangan tanpa mematikan terlebih dahulu dapat menyebabkan kebakaran.

4. Menyebabakan menipisnya lapisan ozon.

C. Faktor-faktor penyebab remaja merokok a.faktorsosial

Faktor terbesar dari kebiasaan merokok dipengaruhi oleh faktor sosial atau lingkungan, dimana karakter seseorang 
banyak dibentuk oleh lingkungan sekitar,baik keluarga, tetangga, ataupun teman

pergaulannya.Bersosialisasi merupakan cara utama pada anak-anak dan remaja untuk mencari jati diri mereka.Dengan melihat apa yang dilakukan orang lain dan kadang kala mencoba untuk meniru apa yang dilakukan orang lain.Hal itu merupakan suatu proses yang terjadi pada remaja untuk mencari jati diri dan belajar menjalani hidup bersosial.Namun sangat disayangkan, tidak hanya kebiasaan-kebiasaan yang baik saja yang ditiru melainkan juga kebiasaankebiasaan buruk, termasuk kebiasaan merokok.

b. Kebutuhan menghisap dan mengunyah

Setiap orang memiliki kebutuhan untuk mengisap dan mengunyah. Kebutuhan ini mulai ada sejak kita lahir yaitu kebutuhan untuk minum susu, dan secara berangsur-angsur berkurang dan hilang, tetapi pada beberapa orang masih ada sampai dewasa. Beberapa orang menggunakan rokok atau perangkat merokok dan asap sebagai sarana untuk memenuhi kebutuhan ini.

c. Responmengulangoto matis

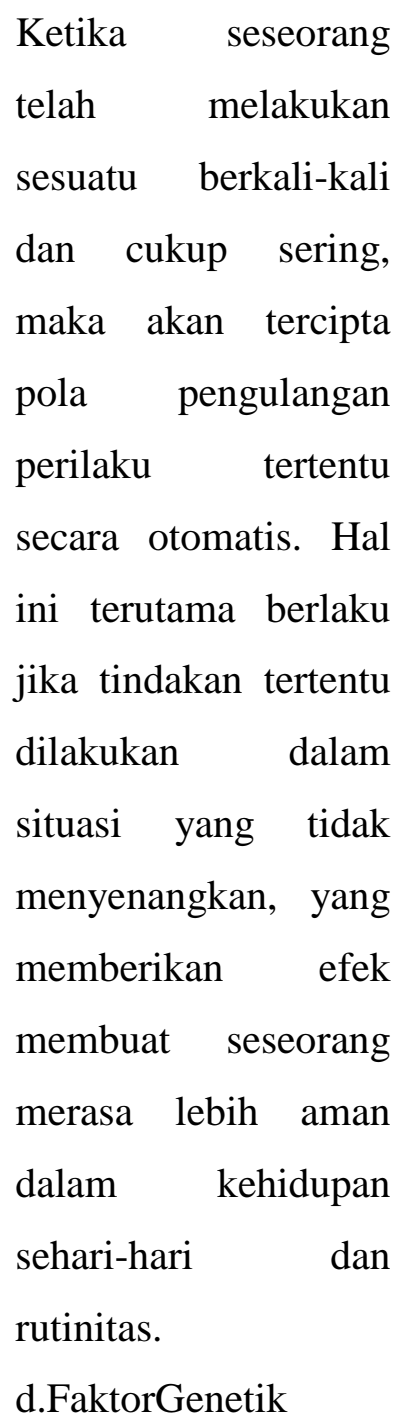

Tidak semua orang sangat tergantung pada nikotin. Ada beberapa orang yang lebih mudah kecanduan nikotin daripada yang lain, dengan alasan yang 
masih susah untuk

dipahami. Dan alasan-

alasan tersebut

diyakini

diwariskandalamkode

genetik.

e.KecanduanPadaSelS

yaraf

Otak secara normal memiliki substansi-

substansi yang

memberikan efek

penenang dan efek

rangsangan pada sel-

sel saraf, dimana

substansi-substansi

tersebut bekerja

dengan cara

menempel pada

reseptor-reseptor sel-

sel saraf. Dan nikotin

memiliki efek yang

sama dengan

substansi-substansi

tersebut terhadap

saraf, ketika nikotin

menempel pada

reseptor-reseptordisel-

selsaraf.

Dengan menempelnya

nikotin pada reseptor,

maka otak

memproduksi

dopamin. Dopamin

inilah yang memberikan efek

menenangkan dan

merangsang organ-

organ lain, yang

memberikan efek

menyenangkan dari

merokok..

\section{Kesimpulan}

Hampir semua remaja di indonesia membudayakan merokok sebagai aktifitas biasa sedangkan bahaya rokok yangberdampak buruk bagi kesehatan ataupun bagi orang lain, penyakitnya pun tidak biasa hingga menyebabkan kematia. Dorongan untuk berhenti merokok untuk remaja yaitu niat dari diri sendiri dan juga dorongan dari orang lain. Yang bisa di lakukan yaitu mengadakan penyuluhan tentang bahayanya merokok. Kalau tidak di hentikan sejak dini akan berdmpak buruk di hari tua nanti. 


\section{Daftar Pustaka}

Randukan,p. 2013. Karya tulis ilmiah

bahaya merokok.

http://pratiwirandukan.blogspot.co

$\underline{\mathrm{m} / 2013 / 02 / \text { karya-tulis-ilmiah- }}$

bahaya-merokok.html?m=1. 27

Mei 2018 (15:29)

Azzard.2015.contoh makalah tentang

pengaruh merokok bagi anak di

bawah umut terhadap perilaku dan

pergaulan sehari-hari.

http://azarrd.blogspot.com/2015/02

/contoh-makalah-tentang-

pengaruh-merokok.html?m=1. 26

Mei 2018 (09:46)

Enha,D.2012. Coretan Sebuah Kisah.

http://dedyenha.blogspot.co.id/201

2/03/makalah-perilaku-merokok-

pada-remaja.html?m=1. $26 \mathrm{Mei}$

2018 (11.02)

Perdana,S. 8 kandungan dalam rokok

an bahaya bagi tubuh.

https://hellosehat.com/pusat-

kesehatan/berhenti-merokok/8-

kandungan-berbahaya-dalam-

rokok-dan-pengaruhnya-pada-

tubuh.html?m=1. 27 Mei 2018

(11.20)

Siyoto, S., \& Sodik, M. A. (2015). Dasar

Metodologi Penelitian. Yogyakarta:

Literasi Media Publishing 